\title{
Libraries in the Cyberage
}

\section{A report from the symposium at Winthrop University}

\author{
by Ron Chepesiuk and Mark Y. Herring
}

$\mathrm{T}$ his past fall, the Dacus Library of Winthrop University in Rock Hill, South Carolina, sponsored four forums as part of a symposium on "Libraries in the Cyberage."

Funded in part by a South Carolina Humanities Council grant, the symposium addressed four key issues regarding the impact of the cyberage on materials in the humanities and their care in libraries: "Censorship and the First Amendment" (September 14 at Winthrop University), "Electronic Publishing and the Furure of Scholarship" (October 3 at the county library in Greenville), "Copyright: Who Owns What in Cyberspace?" (November 1 at the College of Charleston in Charleston), and "The Impact of Digitized Collections on the Humanities" (December 4 at Winthrop University).

\section{The great divide}

The first forum sparked a lively debate between Carrie Gardner, chair of the American Association of the School Librarians Intellectual Freedom Committee, and Carol Clancy, and senior counsel of the conservative National Law Center. Gardner defended the ALA's intellectual freedom viewpoint by arguing that all expression is protected under the First Amendment.

"American citizens are so comfortable with the First Amendment right to receive informa- tion," Gardner said, "that they don't realize what kind of world they would live in if they didn't have it."

She went on to defend the library's right to present information by strongly stating that libraries are the last noncommercial enterprise engaged in supporting our right to receive information. Carol Clancy defended the opposition viewpoint by defending filtering and claiming that not only did the First Amendment "not protect the obscene and/or pornographic," but that South Carolina law also forbids the trafficking in "pornography."

She further argued that information has never been defined as pornographic or obscene and that the First Amendment not only restricted speech but was very clear in its prohibition of certain types of speech per se. "Shouting 'fire' in a crowded theater when no fire was present was strictly forbidden by the First Amendment," Clancy said. "Besides, other Supreme Court cases have revealed that speech in a library, including even political speech, had not only been restricted, but upheld, by the Supreme Court."

The debate was spirited but civil, and it showed the great divide existing over the fon m's topic. As one Winthrop faculty member in attendance noted, "This debate shows why issues involving the First Amendment and cyberspace have been tough to resolve."

\section{About the authors}

Ron Chepesiuk is head of special collections at Winthrop University, chepesiukr@winthrop.edu, and Mark Y. Herring is the dean of the Winthrop Library, e-mail: herringm@winthrop.edu 


\section{The status of electronic publishing}

The second forum's topic was the current state and future direction of electronic publishing. Author Ron Chepesiuk outlined the current state of e-publishing and said that, "While the industry is in its infancy and experiencing growing pains, it won't go away. So librarians should begin experimenting with the new mediun.'

He summarized some of the interesting experiments with e-books going on at such libraries as North Carolina State University and the Algonquin Area Public Library in Illinois. Noting some of the technical challenges in adopting e-books, the speakers argued that the library profession should involve itself more in the decisions being made about the development of e-books.

Angela Adair-Hoy, owner of BookLocker, a successful e-publishing company and the author of the best-selling e-book, The Secrets of Our Success, made an enthusiastic case for e-publishing. "Not only are e-books easy, quick, and inexpensive to publish, they represent an exciting opportunity for authors to get their works before the public," she said. Adair-Hoy took the audience through a tour of her own success in e-publishing and predicted that, within a few years, e-publishing will become the dominant form of publishing.

John Mulchniki of Questia Media, an Internet startup company with the mission of being the source for humanities and social science research on the Internet, startled librarians in attendance with his revelation that his company will launch a 50,000-book cligital library this January. The books will be searchable by word for free, while access to the full text will be available either through annual subscription or time or page.

"Researchers will be able to have information at their fingertips whenever they want," Mulchiki said.

\section{Three sides of the copyright issue}

Forum three brought together copyright experts from three different vantage points: the U.S.Copyright Office (Marybeth Peters, Register of Copyright); the author (Sara Bewley of the National Writer's Union); and the Copyright Clearing House, the world's largest licenser of reproductive rights (Edward Colleian).
". . . books won't be replaced in your or my lifetime, and humanists will continue to view the printed book as the supreme embodiment of the text."

The highlight of Peters's talk was her explanation of the recent contentious ruling made by the Library of Congress at her recommendation. The October 26, 2000, ruling in effect gives copyright users more control over the way people use books and other media by endorsing a new federal law that makes it illegal not to break technical safeguards for such works. "The library community disagrees with me, and I'm not saying that their arguments weren't reasonable," Peters said. "It's just that, in our opinion, it wasn't what the law provided."

Bewley portrayed writers as being allies of librarians on the copyright issue and explained why freelance writers, who are generally underpaid, were forced into the landmark law suit, Tasini $v$. New York Times. Colleran wrapped up the forum by explaining how the Copyright Clearing House works to support writers and authors while protecting copyright.

\section{Paper or digitized?}

The last forum addressed the question: with more and more collections appearing in digitized form, what future is there for paper?

Both J. Edward Lee (associate professor of history at Winthrop University) and Ravi Sharma (director of the West Virginia State College Library in Institute) agreed that digital collections have a place in libraries and may, in fact, be the future of libraries, but that there will always be a place for brick and mortar libraries and seeing "materials in the raw."

"I can assure you that books won't be replaced in your or my lifetime, and humanists will continue to view the printed book as the supreme embodiment of the text," Sharma saicl.

\section{Note}

1. A copy of the complete proceedings will be published by the College of Charleston spring 2001. Contact the authors for details. 


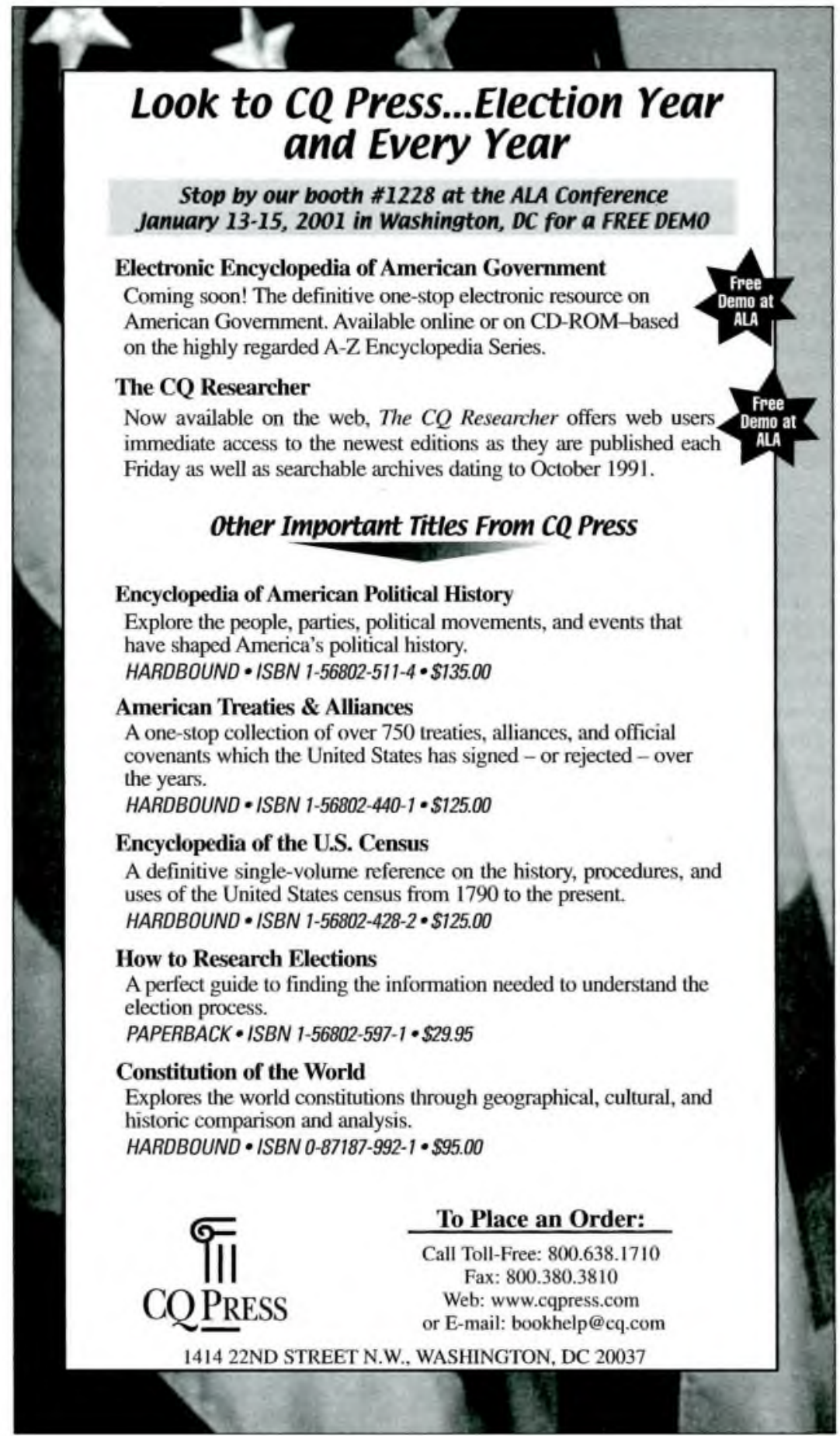

